\title{
Föräldrakontakt och \\ familjetillhörighet ur \\ fosterbarns perspektiv
}

\author{
GUNVOR ANDERSSON
}

Barn får alltmer komma till tals med sina erfarenheter och synpunkter och börjar även få framträda som informanter

i social forskning. I ar tikeln presenteras ett forskningsprojekt, där 22 barn i familjehem, alla i 10-11-årsåldern, intervjuatsi frågor som rör derasförhållandetill såväl biologisk familj som fosterfamilj. D et visar sigatt alla barnen har kontakt med sin mamma och hälften av dem också med sin pappa, men det hindrar inteatt deraskänsla av familjetillhörighet även finnsi foster familjen eller bara där.

Barn placeras vanligen i fami ljehem för att deras föräldrar bedöms ha bristande omsorgsförmåga eller vara olämpliga för sin föräldrauppgift på grund av sociala missförhållanden i hemmet och t.ex. missbruk, psykisk sjukdom, förståndshandikapp. För barn under tolv år är barnens eget beteende ingen grund för vård utanför det egna hemmet, de är aldrig ’beteendefall «i lagens mening utan »miljöfall « $0 \mathrm{~m}$ föräldrarna ger sitt samtycke till vården, placeras barnen enligt SoL (Socialtjänstlagen) och om de

Gunvor A ndersson är docent i socialt arbete och lektor vid Social högskol an, Lunds Universitet. motsätter sig vården, placeras barnen enligt LVU (Lagen med särskilda bestämmelser om Vård av Unga). Tidvis har det varit en mycket kontroversiell fråga, om det är bäst för barnen att få långsiktig trygghet och stabilitet i sitt fosterhem (familjehem) eller om det är bäst för dem att få behålla nära och kontinuerliga relationer till föräldrar och anhöriga, med siktet inställt på att flytta hem så snart som möjligt. Även i tider när frågan är mindre kontroversiell och det råder enighet om att minimera antalet fosterhemsplaceringar, underlätta fortsatt föräldra-barn-kontakt och arbeta för återförening, har cirka 12000 barn (0-17 år) någon gång 
under ett år pågående vård i familjehem. För en del av dem har denna vård pågått under en följd av år (Socialtjänst 1997:11).

Hur ser barn i familjehem (fosterbarn) själ va på pl aceringen, på den fortsatta kontakten med sina föräldrar och på rel ationerna till såväl (ursprungs)familj som fosterfamilj? Det var några av de frågor jag ville ha svar på i forskningsprojektet »Är det annorlunda att vara fosterbarn? ${ }^{\circledR}$ och som denna artikel också handlar om. Först ger jag en motivering till varför jag $\mathrm{i}$ artikel $\mathrm{n}$ begränsar mig till barns perspektiv och barnintervju som forskningsmetod samt till frågor om fosterbarns föräldrakontakter och familjerelationer. Efter en beskrivning av tillvägagångssättet i forskningsprojektet kommer en resultatredovisning. Den börjar med att ge en bild av vilka som utgör barnens fosterfamilj respektive (biologisk) familj. O rsakerna till placeringen får minimalt utrymme för att istället lämna plats för barnens uppfattning i frågor som rör föräldrakontakter och familjerelationer. På grundval därav kan barnen delas in i två grupper, en grupp som har sin familjetillhörighet i fosterhemmet, även om de har kontakt med sina föräldrar, och en grupp som har familjetillhörighet såväl i fosterfamiljen som i (biologiska) familjen, vilket vanligen betyder mammans familj.

\section{O $\mathrm{m}$ barns perspektiv}

Barnperspektiv är ett begrepp, som används al lt oftare, både inom barnforskning och andra verksamheter, som rör barn. Det hör

1 Socialvetenskapliga Forskningsrådet har finansierat foskningsprojektet, som har titeln »s there a difference in being a foster child?« ihop med en ny syn på barn och barndom, en ny betoning på barns rätt att komma till tals med sina erfarenheter och synpunkter och del ge sitt perspektiv på frågor som rör dem (se t.ex. Andersson et al, 1996; Barnombudsmannen, 1994; Konventionen om barnets rättigheter, 1990; O akley, 1994; SoS-rapport 1996:19; SO U 1994:139; SOU 1997:116; Q vortrup et al, 1994; Rasmusson, 1994). Uppfattningen om barnet som en sakkunnig informant är också uttryck för en forskningsstrategi, menar Per Olav Tiller (1991), som associerar begreppet barnperspektiv först och främst till hur världen ser ut för barn: Det är vad barnen ser, hör, upplever och känner, som är deras verklighet. Eftersom barnforskningen i så påfall lande liten grad har ansett barnet vara en brukbar informant om sin egen situation, har vi fått vår kunskap om barn från föräldrar, läkare, barnavård spersonal och lärare, påpekar Tiller. När det gäller forskning om barn, som omfattas av socialtjänstens insatser, kan det tilläggas att information ofta har inhämtats från social sekreterare, sociala akter och olika register, sällan från barnens själva. Ian Butler och Howard W illiamson (1994) visar at bristen på barnorientering i socialt arbete - och i forskning i socialt arbete - inte bara gäller vårt land utan även andra länder. Det innebär inte, påpekar författarna, at barns och vuxnas intressen är så olika eller motsatta, som somliga hävdar, men att det finns skillnader i barns och vuxnas sociala världar, som inte kommer fram i den magra forskningslitteraturen inom området.

Psykologin, särskilt utvecklingspsykologin, har kritiserats för att i al ltför hög grad ha intresserat sig för hur barn utvecklas efter generella linjer, utan att ta hänsyn till klass, kön, 
etnisk till hörighet och kulturell bakgrund. På senare tid har större hänsyn tagits till kontexten el ler det sammanhang, i vilket barnet ingår, men alltför ofta är barnet objekt för undersökning snarare än subjekt. A gnes Andenæs (1991) påpekar vikten av att göra barnet till medforskare istället för undersökningsobjekt och därigenom få tag i barnets egen förståel se av sig själv, sitt liv och det sociala sammanhang, i vilket det ingår.

Sociologin, särskilt socialisationsforskningen, kan på motsvarande sätt kritiseras för att ha varit alltför upptagen av att ta reda på hur barn formas av samhäl let, familjen, de vuxnas villkor (se t.ex. Q vortrup et al, 1994). Barn har i alltför hög grad betraktđs som passiva objekt för omvärldsinflytande. Dock har på senare tid barn börjat betraktas som kapabla personer involverade i en socialisationsprocess, som inte verkar på dem utan via dem (Halldén, 1994). Allison J ames och A lan Prout (1990) är några av dem, som visar att synen på barndomen som social konstruktion ger en god förståelseram för kontextualiseringen av de tidiga åren i livet. Att barnet ännu är biologiskt omoget är ett biologiskt faktum, men sätten på vilket denna omogenhet förstås och ges innebörd är kulturellt betingade. Det är dessa kulturella olikheter som gör barndomen till en social konstruktion. Därav följer att man alltid måste se barnet i sitt sammanhang och att det finns en rik variation på barndomar snarare än en universell barndom. Dessutom är barn aktiva subjekt i konstruktionen eller utformningen av sina egna sociala liv, inte bara passiva objekt för socialastrukturer och processer. Det blir då, som författarna framhåller, viktigt att förstå social realitet genom att ta reda på dess inne- börd för deltagarna i det sammanhang, där det äger rum.

Barn i familjehem ingår i ett sammanhang, som ot vivelaktigt påverkar deras barndom, men de har osynliggjortsi socialt arbete (A ndersson, 1991; Claussen, 1992; Egelund, 1997) och de har sällan använts som informanter i forskning om fosterbarn och familjehemsvård, vilket flera forskare har uppmärksammat (Gardner, 1996; Johnson, Yoken \& Voss, 1995; Thoburn, 1990, 1994; Triseliotis, Sellick \& Short, 1995; Vinnerljung, 1996 a,b). Det var min ambition i forskningsprojektet »är det annorlunda at vara fosterbarn«att genom intervjuer med barn i familjehem försöka förstå deras perspektiv.

\section{Om föräldrakontakter och familjerelationer}

Barn i familjehem har flyttats hemifrån, upplevt separationer, kanske upprepade separationer och omplaceringar, de kan ha förlorat kontakten med sin bakgrund, de kan ha bibehållit kärleksfyllda eller problemfyllda relationer till ursprungsfamiljen, de kan ha fătt nya bärkraftiga relationer i fosterfamiljen eller de kan leva i ett känslomässigt tomrum. Hur det förhåller sig med fosterbarns familjerelationer är av central betydelse för deras identitet och välbefinnande, i synnerhet utifrån objektrelationstänkande (i vid mening) och anknytningsteori (attachment theory), det framgår av rikhaltig litteratur inom området (se t.ex. Andersson, 1995; Börjeson \& Håkansson, 1990; Holmes, 1993; H owe, 1995; Lindén, 1982).

Somliga har framför allt betonat vikten av att garantera stabilitet och varaktighet i 
de nya relationer, som skapas mellan fosterbarn och deras fosterföräldrar, och tal ar för permanent placering. Andra har framför allt betonat vikten av att fosterbarn håller kontakt med biologiska föräldrar för att underlätta den personliga identitetsutvecklingen, och talar för återförening. I vårt land är det framför allt de forskare, som genomförde Barn i kris-projektet (Börjeson, 1976; Börjeson \& Håkansson, 1990; C ederström $\&$ Hessle, 1980; Cederström, 1990, Hessle, 1988; Lindén, 1984; Vinterhed et al, 1981), som lyft fram skillnaderna i de båd a synsätten och bidragit till att förankra ett »relationsorienterat«synsätt i förhållandet mellan fosterbarn och (ursprungs)familj.

Barn placeras vanligen inte i familjehem på grund av störda relationer till föräldrarna utan på grund av ställ Iningstaganden om föräldrarnas bristande omsorgsförmåga och sociala missförhållanden i hemmet (A ndersson, 1984, 1991; Hollander, 1985; Vinnerljung, 1996 a, b). Man kan av dylika ställningstaganden inte dra slutsatser om föräldra-barn-relationer och det är numera socialtjänstens lagstadgade uppgift att medverka till att goda relationer består, dåliga relationer förbättras och nya etableras, där inga finns. Kontakt är en viktig förutsättning för relationer, men även utan nära relationer har barn rätt till kontakt med sin ursprungsfamilj, som en del av sin historia, sitt ursprung, sin identitet. Det betonas i lagen att vård utanför det egna hemmet bör utformas så att den främjar den enskildes samhörighet med anhöriga och kontakt med hemmiljön samt att inriktningen bör vara återförening (SOU 1986:20; SOU 1994:139; Prop.1996/97:124). Det har emellertid visat sig att socialtjänsten inte tillräckligt aktivt medverkar till att föräldrar och barn i familjehem upprätthåller kontakten med varandra och till att de återförenas (Fami ljehemsvård i utveckling, 1995; SoS-rapport 1990:4; Riksdagens Revisorer 1990; Rskr 1992/93:16).

Hur barn, som far illa i sitt hem, bäst ska garanteras stabilitet, trygghet och kontinuitet i viktiga relationer, har diskuterats i flera länder. Strävan kan i första hand vara đtt göra sociala insatser för att åstadkomma detta i hemmet, vilket fick genomslag t.ex. i USA (ofta med hänvisning till Fanshel \& Shinn, 1978) eller att garantera detta i fosterhem/adoptivhem, vilket fick genomslag i Storbritannien (ofta med hänvisning till Goldstein, Freud \& Sol nit, 1978). N är man i USA satsđ på intensiva insatser i hemmet, har det dock funnits en tidsbegränsning. O $\mathrm{m}$ familjesituationen inte förbättrats tillräckligt inom ett och ett halvt till två år blir permanent fosterhemsplacering eller adoption aktuellt (Barth, 1992). Detta förfarande kan kritiseras från två håll, intensivt familjearbete ger inte barn tillräckligt skydd (Wells\& Tracy, 1996) och permanent placering i foster- eller adoptivhem ger inte barnen familjekontinuitet (Barth, 1996; McFadden \& W hitelaw Downs, 1995). I Storbritannien har betoningen på permanent placering och adoption kritiserats för at gå för långt (G illigan, 1997). Den nyalagstiftningen har där tagit intryck av Dartington-gruppens forskningsrapporter och betonar istället samarbete (partnership) med föräldrarna och bibehållen kontakt mellan barn i famil ljehem och föräldrar och syskon (M illham et al, 1986, 1989; Patterns \& 0 utcomes in Child Placement, 1991; se även Triseliotis, Sellick \& Short, 1995). 
June Thoburns (1994) finner i sin genomgång av barnavårdsforskning att de båda begreppen stabilitet och identitet rymmer det, som vanl igen framhålls som särskilt viktigt för barn: varaktighet (trygghet och stabilitet i kärlek, familjeliv, vardagsliv) och identitet (behålla kontakt med viktiga personer i det förflutna, ha kontakt med ursprungsfamilj, integrera det nuvarande med det som varit, få vara den man är). Det gäller att upprätthålla balans mellan dessa båda begrepp i barnavårdsarbetet. I första hand gäller att arbeta för ökad trygghet och stabilitet i familjen, så att barnet kan växa upp i sin ursprungsfamilj. I andra hand kan trygghet och stabilitet till godoses genom familjehemsplacering och identitet genom bibehållna relationer till föräldrar, syskon och andra viktiga personer. Det stora problemet är inte hur föräldrars fortsatta kontakt med barn i familjehem ska regleras eller begränsas, för att inte skada barnen. Det stora problemet är, menar Thoburn, hur man ska hjälpa och uppmuntra föräldrar att bibehålla kontakten för barnens skull, även om det kan vara smärtsamt för dem själva.

I min egen tidigare for skning (A ndersson 1984, 1988, 1990, 1995) fann jag brist på denna »balans« En del barn i familjehem hade blivit sina fosterföräldrars barn i ett stabilt familjehem men hade tappat all kontakt med sin ursprungsfamilj. Andra barn hade upplevt instabilitet i växlingar mellan familjehem eller mellan familjehem och hem. $N$ ågra få barn hade behållit en relation till såväl familj som fosterfamilj, men det fanns också barn, som lämnats i ett tomrum. H ur är det idag för barn i familjehem, i en tid när det råder (förhållandevis) stor enighet om att det är viktigt för dem att få behålla kontakt med familj och anhöriga? Sker det? Är siktet instält på återförening? Hur ser barnen själva på föräldrarel ationer och familjetillhörighet?

\section{Tillvägagångssätt}

\section{Urval av barn}

Fyra sydsvenska kommuner, med olika befolkningsstruktur och olika organisation av familjehemsvården, kontaktades (varav en begränsning gjordes till två kommundelar i den största kommunen). I u rvalet ingick al la barn, som vid tiden för intervjun (andra halvåret 1995 och första halvåret 1996) var 10-11 år gamla (födda 1984- 85 respektive 1985-86) och bodde i familjehem. Barn i akut- eller jourhem togs inte med och inte heller barn med svåra handikapp (utvecklingsstörning, autism). Det betyder att 31 barn ingick i urvalet, men det blev ett bortfall på nio barn. Tre föräldrar sade nej för sina barns räkning, tre fosterföräldrar sade nej, antingen för att de själva inte ville ta emot mig eller för att de inte ville utsätta barnen för intervju, och tre barn lät själva hälsa att de inte ville. Det betyder att 22 barn intervjuades. De kom från fyra kommuner men bodde i familjehem i 14 olika kommuner.

Med utgångspunkten att barnens ålder är av betydelse för deras perspektiv på tillvaron, deras sätt att förmedla sina erfarenheter, tankar och upplevel ser i en intervjusituation och deras förmåga att reflektera över sin situation, valde jag barn i samma ålder. Barn i 10-11-årsåldern har en kognitiv utvecklingsnivå, som gör sjävreflexion möjlig, de kan uppfatta och tolka andras beteenden och kan göra sociala jämförelser, de kan för- 
stå skillnaden mellan inre känslor och yttre uttryck och föra orsaks-resonemang ( $\mathrm{G}$ arbarino \& Stott, 1992; Stone \& Lemanek, 1990). I denna ålder kan också de samhälleliga värderingarna av kvinnligt och manligt få stor betydelse, påpekar bl.a. H arriet Bjerrum Nielsen och Monica Rudberg (1991). I många undersökningar har man funnit att flickor bemästrar svåra uppväxtförhål landen bättreän pojkar, särskilt i tidig barndom och mellanbarndom (Rutter, 1990; Werner \& Smith, 1982, 1992). I forskning i socialt arbete med barn är genusaspekter emellertid föga uppmärksammade. Jag hade intentionen att få med ungefär lika många flickor som pojkar i urvalet och det föll sig så att av de 22 barnen var 10 flickor och 12 pojkar.

\section{Intervjuernas genomförande}

Barnen intervjuades vid tre tillfällen med en eller ett par veckors mellanrum. Upprepade intervjuer var en stor fördel av flera skäl: Resultatet av intervjun är beroende av att relationen mellan intervjuaren och barnet är god (Eide, 1989; G arbarino \& Stott, 1992) och det tar viss tid att skapa en sådan relation. Barn lever här och nu och utgår från den konkreta verklighet, som gäller när intervjun äger rum, och med en enstaka intervju finns risk för att intervjuaren drar alltför långtgående slutsatser av tillfälliga händel ser. I möte med barn är det viktigt att inte vara pressad av tiden. Upprepade intervjuer gav möjlighet för båda parter att korrigera eller förtydliga oklarheter, framför allt gav det mig möjlighet att lyssna på bandinspelningen av föregående intervju och återvända till ett ämne, som det visade sig att jag avbrutit eller missförstått.

Intervju är en bestämd form av kommu- nikation, en verbal kommunikationsprocess. $0 \mathrm{~m}$ svaren på enskilda frågor inte påverkar vilka frågor som därefter ställs eller det sätt på vilket de ställs, kan man knappast tala om en interaktion, påpekar Per Olav Tiller (1988). Därför är sden öppna intervjun «att föredra, en lågt standardiserad och lågt strukturerad intervjuform (Kjær Jensen, 1988), men en fokuserad intervju, där samtalet är tillrättalagt av forskaren för at få den intervjuade att beskriva hur händelser eller fenomen ter sig för honom eller henne (Andenæs, 1991). Ian Butler och H oward Williamson (1994), som har erfarenhet av att intervjua barn, som omfatas av sociala insatser, motiverar den öppna intervjun så här:

Tal king to children and young people does not lend itself to tight structures and defined sequences. Children jump around and researchers have to jump around with them, seizing opportunities to probe and explore issuesfurther (s.30).

\section{Intervj uernas innehåll}

Hur frågar man ett barn i familjehem om föräldrakontakter och familjerelationer? Det gäller att tänka efter vilka konkreta beskrivningar och vilka vardagliga händelser och situationer, som avspeglar det som intervjuaren vill veta något om. Det ökar barns trygghet $\mathrm{i}$ intervjusituationen att få börja med det konkreta och välkända och få känna att de bemästrar situationen (Vestby, 1991). Därför började jag med att be barnen skriva en lista på vilka personer, som bodde i familjehemmet. Även om vi hade bandspelare var det bra att ha alla namn framför sig och veta vem barnet fortsättningsvis talade om. Listan gav utgångspunkt för samtal om 
vad barnet använde för begrepp för familjehem och olika familjemedlemmar samt gav utgångspunkt för beskrivningar, som sade något om relationen till de olika familjemedlemmarna.

I anslutning till frågor om hur länge barnet bott i familjehemmet och anledningen till placeringen bad jag att få mammans namn på listan, vilka hon bodde tillsammans med och vilka som i övrigt tillhörde familjen. Följdfrågor kunde handla om hur, var och när de träffades och samtal om vad de gjorde, när de träffades senast. På motsvarande sätt samtalade vi om barnets pappa.

En lista, som var överskådlig och som vi kunde fylla på efter hand, var mycket bra som utgångspunkt för samtal om kontakter och relationer. Det kunde ta ganska lång tid att förklara al la namn för mig, men dessa listor tror jag gav en tydligare bild av de komplicerade familjemönster, som de flesta barn befann sig i, än de nätverkskartor, som jag funderat på att använda (jfr Hagbard \& Esping, 1992). För att på ytterligare ett sätt få veta något om kvaliteten i barnens rel đtioner bad jag dem skriva en lista på vilka personer, som betydde mycket för dem, var viktiga för dem. Det visade sig att de inte hade några svårigheter att bestämma sig för vilka som skulle vara med eller i vilken rangordning de skul le komma.

Det fanns också andra teman i mina intervjuer med barnen, t.ex. sådana som handlade om deras vardagsl iv hemma, i skolan och på fritiden, men de berörs inte i denna artikel. För utförligare information om utgångspunkter och tillvägagångssätt i forskningsprojektet hänvisas till artikeln »Barnintervju som forskningsmetod « (An- dersson, 1998).

I denna artikel berörs inte de efterföljande intervjuerna med fosterföräldrar, biologiska syskon i familjehemmet, fosterföräldrarnas jämnåriga barn eller intervjuerna med biologiska föräldrar. I de fall jag ansett det nödvändigt att ta med någon uppgift från fosterföräldrarna (t.ex. om tidigare placeringar och paragraf), har det angetts.

\section{Barnen och fosterfamiljen}

De 22 barnen bodde i 21 fami ljehem, eftersom två syskon bodde i samma hem. J ag väljer fortsättningsvis benämningarna familjehem eller fosterhem, fosterföräldrar och fosterbarn, eftersom det är dessa benämningar barnen själva använder. Tabell 1 visar barnen i undersökningsgruppen, hur gamla de var när de kom till det aktuella familjehemmet samt vilka de bor tillsammans med. Det är fostermamma (f-mor) och fosterpappa (f-far), fosterföräldrarnas egna (biologiska eller adopterade) barn (pojkar = po och flickor =fl) och andrafosterbarn (fosterpoj$k a r=f-p o$ och fosterflickor $=f-f l)$. De foster barn, som är min intervjuper sons biologiska syskon, anges med fetstil. Eftersom alla intervjupersonerna var 10-11 år, anges inte deras ålder (tre hade inte hunnit fyllatio vid första intervjutillfället och fyra hade fyllt elva), medan övriga barns ålder anges. Begrepp som f-mor och f-far är mitt förtydligande, eftersom de för en del barn var mamma och pappa, liksom f-po och f-fl är mitt förtydligande, eftersom al la barn i huset benämndes syskon.

Som framgår av tabell 1 (se nästa sida) var variationen stor. Två barn bodde som enda barn med sina fosterföräldrar, som i 
Tabell 1.

Barnen i rangordning efter ålder vid placeringen samt övriga, som bor i familjehemmet.

\begin{tabular}{|c|c|c|c|c|}
\hline$\overline{\text { Barn }}$ & Álder vid plac. & F-föräldrar m. & egna barn & Andra fosterbarn \\
\hline Anna & $<1 \mathrm{agr}$ & $f-m o r, f-f a r$ & po 15 & \\
\hline Bengt & $<1$ år & f-mor, f-far & po 19 ,fl 15 & $f-f l 5$ \\
\hline Cecilia & $<1$ år & f-mor, f-far & po 13, po $12, f 17$ & \\
\hline David & $<1$ år & f-mor, f-far & & \\
\hline Eva & $<1$ år & f-mor, f-far & & f-fl 22,f-po 18 \\
\hline Frida & 1-3 år & f-mor & & \\
\hline Gunnel & 1-3 år & f-mor & fl 12,po 11,fl 5 & $f-f l 18, f-f l \mid 15$ \\
\hline Hanna & $1-3 a ̊ r$ & f-mor, f-far & & $f-f l 17, f-f l$ 9,f-fi 9 \\
\hline Irene & $1-3 \mathrm{a} r$ & f-mor, f-far & & f-po 15 \\
\hline Jakob & 1-3 år & f-mor, f-far & & f-po 15 \\
\hline Kalle & 3-5 år & f-mor, f-far & & f-po 14, f-fl 12 \\
\hline Lasse & 3-5 år & f-mor, f-far & & f-po 8 \\
\hline Malte & 5-7 år & f-mor, f-far & & f-po 14,f-po 13,f-fl 12 \\
\hline $\mathrm{N}$ ils & 5-7 år & f-mor, f-far & po 31 & f-po 14 \\
\hline 0 lga & 5-7 år & $f-m o r, f-f a r$ & po 19 & f-fl 15,f-po 7,f-fl 4 \\
\hline Petra & 5-7 år & f-mor, f-far & fl $11, f l 9$ & f-fl 15 \\
\hline Rasmus & 5-7 år & f-mor, f-far & ff $19, p o 16, f l 13$ & f-po 4 \\
\hline Sven & 7-10 år & f-mor, f-far & & \\
\hline Tobias & $7-10$ år & f-mor, f-far & po 10 & f-fl 14,f-fl 14,f-po 11 \\
\hline Ulla & 7-10 år & f-mor, f-far & fl 16,fl 16,po 11,fl 7,po 5 & \\
\hline Viktor & 7-10 år & f-mor, f-far & & f-po 13,f-po 12 \\
\hline & & f-mor, f-far & po 10 & f-fl 14,ffl 14,f-po 10 \\
\hline
\end{tabular}

bådafallen var morföräldrar. Fyra barn bodde som enda fosterbarn tillsammans med sina fosterföräldrar (som i ett fall var moster) och deras egna barn. Åtta barn bodde till sammans med sina fosterföräldrar (som i ett fall var moster), deras egna barn (inklusive adoptivbarn i två av familjerna) och andra fosterbarn (inklusive biologiska syskon till två av intervjupersonerna). Åtta barn bodde tillsammans med fosterföräldrar (som i ett fall var moster) och andra fosterbarn (inklusive biologiska syskon till fyra av intervjupersonerna), eftersom fosterföräldrarna antingen inte hade egna barn eller också (vilket var vanligare) hade vuxna barn.

$0 \mathrm{~m}$ barnen hade fătt bestämma vilka som skulle vara med $\mathrm{i}$ tabellen, hade troligen flera barn ingåatt. $M$ ånga nämnde något eller några av fosterfamiljens vuxna barn, som nyligen flyttat hemifrån, bodde i närheten eller kom hem så ofta att de egentligen räknades till familjen. För tolv av mina intervjupersoner ingick i beskrivningen av familjehemmet de vuxna barn, som var betydelsefulla för dem. Två av dem nämnde nyss utflyttade fosterbarn, sex nämnde fostermammans barn i tidigare äktenskap och fyra nämnde fosterföräldrarnas gemensammabarn.

Förutom de fosterföräldrar, som hade tidigare äktenskap bakom sig, hade tre av mina intervjupersoner varit med om fosterföräldrarnas skilsmässa. De hade olika sätt 
att förhålla sig till den fosterpappa, som de bott tillsammans med under lång tid, och till fostermammans nya man. Barnen hade nämligen stannat hos sina fostermammor. Två av dem nämnde den utflyttade fosterpappan, som en del av fosterfamiljen och det dröjde, innan jag förstod att de faktiskt inte bodde till sammans längre. I det ena fallet fungerade inte det fortsatta umgänget, till flickans stora sorg, men väl i det andra. För det tredje barnet med skilda fosterföräldrar var det lättare, han var mycket nöjd med sin »nya fosterpappa och träffade den sgamla«ibland. Jag fick lära mig att det gäller att fråga noga för att säkert förstå, hur barnen menar.

\section{Varför placerades barnen i familjehemmet?}

Barnen hade bott olika lång tid $\mathrm{i}$ sitt familjehem, alltifrån sex-sju månader till i det närmaste tio år. D et visade sig (om jag tar hiälp av fosterföräldrarnas information) att för de flesta barnen var det inte deras första placering. De fem barn, som var under ett år när de kom till familjehemmet, hade i princip inte bott hemma alls men hade varit en kortare tid på spädbarnshem el ler i jourhem eller hade bott med sin mamma på barnhem. De sju barn, som var mellan ett och fem år gamla när de kom till familjehemmet, hade efter en första tid hemma hos mamma bott hos pappa eller släktingar en tid eller varit på barnhem eller i jourhem eller bådadera bara ett av dessa sju barn kom direkt från mamma till familjehemmet. Av de tio barn, som var över fem år gaml a när de kom till familjehemmet, hade sex erfarenhet av barnhemsvistelse(r) och längre familje- hemsplacering(ar). Två syskon hade visserligen ingen tidigare placering bakom sig men ett stort antal vistelser med sin mamma i olika jourlägenheter och bara två barn kom direkt hemifrån till familjehemmet (om man inte räknar kortare vistelser i kontaktfamilj).

I barnintervjun uppehöll vi oss inte så mycket vid tidigare placeringar som vid varför de inte kunde bo hemma. De flesta visste ganska klart besked därom. För omkring tre fjärdedelar av barnen var anledningen föräldrarnas eller mammans missbruk och för de andra var det mammans psykiska sjukdom och/eller förståndshandikapp även om barnen inte formulerade det riktigt så. Det var bara en flicka, som inte alls visste varför hon inte kunde bo hos sin mamma, och en pojke, som bara angav den bidragande orsaken: y ag tålde inte att dom rökte, för jag har astma« Även om nästan all a hade ganska klart för sig, varför de inte kunde bo hemma, svarade de ibland wet inte och dröjde med sin förklaring tills de fătt klart för sig att jag tålde att höra, att jag t.ex. träffat barn förut, som var i deras situation. Det framkom också att de flesta hade berättat i skolan eller för kamrater, varför de bodde i familjehem, men en del hade bara berättat det för en särskild kompis, som lovat att inte säga något till de andra. Svårast var att berätta om att mamma eller pappa knarkade el ler hade suttit i fängelse.

\section{Barnen och den biologiska familjen}

Det är vanligt att tala om barnens biologiska familj som en enhet med föräldrar och syskon. I själva verket är det oftast frågan om 
(minst) två enheter, mamma för sig eller sammanboende med en ny man och pappa för sig eller sammanboende med en ny kvinna. Kanske finns nya barn i de nya familjebildningarna och kanske har den nya sambon med sig egna barn från tidigare förhållande. Syskon kan bo kvar hemma hos mamma eller bo i andra familjehem. Det tycks vara vanligare at kalla de barn, som har samma mamma, för syskon och känna närhet till dem, även om de bor i olika familjehem och knappast träffas, än att räkna pappasandra barn som syskon.

Tabell 2 rangordnar barnen på samma sätt som i föregående tabell och ger en översikt över barnens biologiska familj. I kolumnen för »mamma«anges vilka personer, som mamman bor tillsammans med, och i kolumnen för sрарра« anges vilka personer, som pappan bor tillsammans med, i den mån barnen vet det. Barn i endera hemmet anges med ålder för pojkar (po) respektive flickor (fl), sambo/po betyder att sambo har med sig en egen pojke till familjen. I kolumnen för »pappa«står »’or själv«även om han har barn i annat förhållande, som ibland är hos sin pappa samtidigt med min intervjuperson. »Vet ej«kan betyda att fadern är okänd eller att barnet aldrig träffat sin pappa eller att han kommit på enstaka besök, utan att barnet vet något om hans nuvarande familjeförhållanden eller om hans barn, som på intet sätt uppfattas som syskon. Kolumnen för syskon upptar bara syskon i fa-

Tabell 2.

Barnen och den biologiska familjen med mamma, pappa och syskon

\begin{tabular}{|c|c|c|c|}
\hline Barn & Mamma & Pappa & Syskon \\
\hline Anna & mamma och pappa bor ihop & & fl 21 f-hem2,po 12 f-hem3 \\
\hline Bengt & mamma m.sambo & pappa bor själv & - \\
\hline Cecilia & mamma m.sambo & pappabor själv & fl 5 f-hem2 \\
\hline David & mamma bor själv & vetej & - \\
\hline Eva & mamma bor själv & (tror sambo, 6 barn) & - \\
\hline Frida & mamma m.sambo & pappa bor själv & po 17 f-hem2 \\
\hline Gunnel & mamma bor själv & vet ej & fl 10 f-hem2,po 12 f-hem3 \\
\hline Hanna & mamma m.po 4 & vetej & fl 9 f-hem1,po 7 f-hem2 \\
\hline Irene & mamma m.sambo & pappabor själv & 4 äldre syskon annat \\
\hline Jakob & mamma m.sambo & pappa m.fl 2,sambo/po & po 15 f-hem1 \\
\hline Kalle & mamma m.sambo & pappabor själv & po 3 f-hem2 \\
\hline Lasse & mamma död & (tror sambo, 3 barn) & po 8 f-hem1 \\
\hline Malte & mamma bor själv & vet ej & fl 16 f-hem2 \\
\hline Nils & mamma m.sambo & vetej & fl 15,po 18 annat \\
\hline 0 lga & mamma bor själv & pappa bor själv & - \\
\hline Petra & mamma bor själv & vet ej & - \\
\hline Rasmus & mamma m.sambo & pappa bor själv & fl 9 f-hem 2 \\
\hline Sven & mamma m.po 3,sambo & (tror sambo, 3 barn) & - \\
\hline Tobias & mamma m.fl 3 & pappabor själv & fl 14,po 11 f-hem1,po 15 f-hem2 \\
\hline Ulla & mamma m.sambo/po & vet ej & - \\
\hline Viktor & mamma bor själv & pappam.fl 1,sambo/2po & po 12 f-hem 1 \\
\hline Å ke & mamma m.fl 3 & pappabor själv & fl 14,po 10 f-hem1,po 15 f-hem2 \\
\hline
\end{tabular}


miljehem, som anges med f-hem 1 om syskonet är i samma hem, som min intervjuperson, och f-hem 2 eller 3, om det är frågan om andra hem. Äldre syskon (med samma mamma), som bor hos sina respektive pappor (dock inte min intervjupersons pappa) el ler bor själva, noteras som »annat《

Som framgår av tabellen är alla barnen väl bekanta med sin mamma och hennes nuvarande familjeförhållanden. Tio barns mammor bor tillsammans med en ny man och tio barns mammor bor själva, utan ny man, en mamma är död och bara en mamma bor tillsammans med min intervjupersons pappa. Bara tre mammor (till fyra barn) bor tillsammans med yngre barn, men tio mammor har barn också i andra familjehem än det, som min intervjuperson bor i. Barnen är inte lika väl bekanta med sin pappa och hans nuvarande familjeförhållanden. Åtta barn vet inte någonting al ls och tre barn är tveksamma, men elva barn vet klara besked. Det betyder att för hälften av barnen i undersökningsgruppen är deras pappa en verklig del av deras biologiska familj. Syskon i andra familjehem kan vara en viktig del av deras biologiska familj, även om somliga bara träffats en eller några få gånger. A lla syskon, som nämns i tabell 2, har samma mamma som min intervjuperson.

\section{Föräldrakontakt och familjetillhörighet}

Vid en närmare granskning av hur barnen svarar på mina frågor och talar om sina föräldrar och fosterföräldrar, kan de delas in i två grupper med olika kännetecken. Den ena gruppen har sin familjetil lhörighet i fosterfamiljen, där de kallar sina fosterföräld- rar mamma och pappa, och har glesare kontakt med sina föräldrar under kortare besök. Den andra gruppen har tillhörighet både till fosterfami ljen och sin biologiskafamilj, de använder förnamn till sina fosterföräldrar och kallar sina föräldrar mamma och pappa. De rör sig friare mellan de båda familjerna och bor regelbundet över hossina föräldrar (vanligen sin mamma). I det följande beskrivs de två grupperna var för sig och på något olika sätt. Eftersom grupperna är lika stora, vill jag ge dem lika stort utrymme, men den första gruppen låter sig lättare sammanfatas och den andra gruppen omfattar barn med individuella uttryck för sin tillhörighet till två familjer, som jag gärna vill ge läsaren insyn i.

\section{Fosterfamiljen är barnets familj}

För de elva barnen i denna grupp ( 6 pojkar och 5 flickor) är fosterföräldrarna mamma och pappa. Även om al la är medvetna om at de bor i familjehem, påpekar en del av barnen att de brukar kalla fosterfamiljen sin familj och att de inte brukar säga fosterbarn, eftersom de är ett »wanligt «barn i en »wanlig«familj. N ågra barn blev en aning i rriterade över att jag ständigt frågade vem de menade, när de sade »mamma«eller »pappa« Det är ett aktivt val att benämna fosterföräldrarna så. Det kan hända att (biologiska) mamman tycker att barnet ska säga mamma till henne istället, smen det vill jag inte« som en flicka sade. De biologiska föräldrarna kallas vid förnamn utom i ett par fall, där barnet säger mamma till båda, »mamma Titti «eller »mor «för att skilja från den mamma, som de bor hos (fostermamman). Fosterföräldrarna, d.v.s. »mamma«och »pappa« kommer först på listan över viktiga perso- 
ner. Det är för de flesta, som en pojke uttryckte det: »Dom bästa jag tycker om är min mamma och pappa«(och menar då fosterföräldrarna). Tre flickor skriver sin biologiska mammas namn direkt efter fosterföräldrarna (som är mamma och pappa). Sex av barnen tar inte alls med någon av sina (biologiska) föräldrar på listan över viktiga personer, medan två pojkar tar med dem, eller en av dem, längst ner på listan.

Kontakten med (biologiska) mamman har bara i två fall varit regelbunden under så gott som hela barnets vistelse i familjehemmet och då varannan eller var tredje vecka. Vanligare är att det är bestämt att de ska träffas en gång i månaden, men det har inte al ltid blivit så regel bundet utan varit långa uppehåll. Det går oftast till så at mamman kommer till fosterhemmet över dagen eller del av dag, i två fall al ltid tillsammans med barnets mormor och i två fall al ltid tillsammans med en social sekreterare (om jag tolkar barnens beskrivning rätt). I de två fall, som barnet får besöka mamman hemma, är mormor respektive fosterföräldrarna alltid med. De flesta barnen tycker det är roligt, när mamman kommer. Bara en flicka säger att hon inte tycker om sin mamma och helst inte vill träffa henne. De andra tycker det är bra som det är, lagom ofta, och ingen har några önskemål om att det skulle vara oftare.

O $\mathrm{m}$ barnen tycker att det är lagom ofta (som det är bestämt), så finns det ändå för flera av dem besvikelser kopplade till kontakten med mamman. Besök har bestämts och inte blivit av, de har väntat men mamman har inte kommit. En del reagerar inte så starkt: »Bara en gång blev jag ledsen... hon ringde och sa att hon inte kunde komma... nej, hon har gjort det två gånger. «A ndra blir mer upprörda, särskilt om det händer till födelsedagen och särskilt om de inte făr någon rimlig förklaring efteråt, shon bara ljuger « eller ฟhon låtsas inte om det « Det kan vara smärtsamt att tänka på att hon kanske inte bryr sig, för at hon ssuper « eller *narkar « är ingen গförklaring«utan snarare ett tecken på att hon »inte bryr sig«om barnet, »det är dumt, taskigt « En flicka skulle få sova över hos mamman under senaste skollovet, men det dröjde inte länge innan hon ringde hon till smamma (fostermamman) och ville 'hem« Hon vill inte berätta vad hon var besviken på, men arg och besviken lät hon. Den pojke, som flyttade hemifrån långt innan hans mamma dog, tänker fortfarande mycket på att hon nog dog av sorg över att inte få träffa honom. Det är uppenbart att barnens (biologiska) mammor inte är likgiltiga för dem utan förknippade med starka känslor, även om de har »nya«mammor och sitt hem och sin familjetillhörighet i familjehemmet.

Kontakt med pappan (som vanligen inte kallas pappa) har inte alla barn. Fem barn vet inte något om sin pappa, fem barn träffar honom då och då och en flicka har nu regelbunden kontakt, efter flera år utan kontakt. Hon bor över hos sin pappa vart tredje veckoslut och tycks då vara lika mycket hos farmor och farfar som hos pappa. De som har kontakt med pappan då och då, beskriver den annorlunda än kontakten med mamman. För två av barnen är den mer likgiltig, en pojke tycker t.ex. att det räcker att pappan kommer och hälsar på två gånger om året, han kunde varit utan de besöken också, men så tänker han: » ‘ an är ju ändå min pappa« För tre av barnen, alla pojkar, är pap- 
pan av beskrivningen att döma snarast en vuxen kamrat. Det är roligt när han kommer eller när han ringer och säger att barnet kan få komma och hälsa på. $0 \mathrm{~m}$ det dröjer eller inte blir som bestämt, är det lätt att godta att han inte kunde komma t.ex. till födelsedagen »för att han var lösi magen«eller «han hade inte tid« Det är lättare för barnen att berätta vad de gör, när de träffar sina pappor än sina mammor. En pojke säger: »Sen går vi upp på mitt rum och bygger lego, sen fikar vi och så bygger vi lego lite till och sen går han hem. «En annan pojke har nyss haft sin pappa på besök: »yår sajag till honom att han kunde lägga lite hörnor, som jag kunde nicka på, och så gick vi in och drack kaffe och jag drack cider.«En tredje pojke beskriver lådbilen de bygger och hur duktig pappan är på att laga saker.

Barnen i den här gruppen är Anna, Bengt, Cecilia, David, Eva, Gunnel, Hanna, Jakob, Kalle, Lasse och Nils. 0 m vi jämför med tabell 1, finner vi att det i princip är de barn, som kom till familjehemmet före fem års ålder. D et finns bara några få undantag från den »regeln « Ett undantag är tvåflickor i släktinghem (Frid a och Irene), som trots att de placerades tidigt tillhör nästa grupp, som kännetecknas av tillhörighet till två familjer. Ett annat undantag är Nils, som har hela sin familjetillhörighet i familjehemmet, trots att han placerades efter fem års ålder.

Det är inte bara tidig placering och förhållandevis sparsam kontakt med (biologiska) föräldrar, som kännetecknar denna grupp, utan också barnens övertygelse om att de ska bo i sitt familjehem tills de blir stora och flyttar hemifrån. $0 \mathrm{~m}$ framtiden säger de t.ex.ıag ska bo här till jag slutar skolan och sen ska jag väl få jobb«eller » yag ska bo här till jag blir lite mer vuxen och kanskefår ett eget hem « N är vi talar om vad (biologiska) mamman säger om att de bor i fami ljehem, säger några barn t.ex. »M amma är glad att jag kan bo här « A ndra mammor har inte sagt vad de tycker, men de har heller aldrig sagt något om att de skulle vilja at barnen flyttade hem. En flicka tänker att whon kanske inte tycker det är särskilt roligt att jag bor här « men om hon skulle vilja at flickan flyttade hem »då hade jag nog inte sagt nånting, jag hade låtsats som om jag inte hört nåt« Denna flicka vill självklart, som de andrai gruppen, «bo här «

Barnen förmedlar en trygg förvissning om att de både vill och får stanna i sitt (nuvarande) familjehem. Kanske har det att göra med att de är placerade enligt tvångsparagraf (LVU)? Jag frågar fosterföräldrarna och får veta att tre av barnen är pl acerade enl igt LVU, fyra enligt SoL och i fyrafall vet inte fosterföräldrarna vilket: »yag vet faktiskt inte riktigt «- »yag har inte forskat närmare i det « - »Det har ingen betydelse, för dom ska vara här till dom blir vuxna« KänsIan av varaktighet tycks inte komma av lagparagrafer, snarare av en tyst eller uttalad överenskommelse med barnens mamma. ( $\mathrm{fr}$ ' »xpectations of permanence« A Id gate, 1990; "Sense of permanence« Thoburn, 1994.)

Barnen får också reflektera över vad som är annorlunda med att bo i familjehem, ge exempel på skillnader. Jag hade tänkt mig att de skulle göra jämförelser med att bo hemma för egen del. A lla tänkte emellertid på skillnader i förhållande till hur andra barn har det, hur barn »normalt « har det. $\gg$ ej, det är ingen skillnad, inte jämfört med hur andra barn har det «- »D et är som att bo 
i en vanlig familj «- »yag känner faktiskt ingen skillnad «- »N ej, jag tycker det är bra här « - »Andra tycker nog det är skillnad, men jag är väl ungefär som en vanlig. Jag tycker i alla fall att jag har det bra.«Något enstaka barn gör tillägg av typen: »Det är bättre att bo här, för att bo hemma hade varit jobbigt «- »Det är bättre här än där borta, för dom dricker ju och sånt. «Bara när jag frågar om konkreta skillnader mot att bo hemma för deras egen del, kommer några få exempel och då på fördelar med att bo i fosterhemmet och nackdelar med att bo hemma.

Ytterligare en infallsvinkel på hur barnen ser på att bo i familjehem hoppades jag få genom frågan: $\gg 0 \mathrm{~m}$ du skulle träffa någon $\mathrm{i}$ din ålder, som skulle flytta till ett familjehem och som frågar dig: Hur är det att bo i familjehem? Vad skulle du säga då? «Svaren var av typen: »y ag tycker det är som vanligt ungefär. D et är bra. $0 \mathrm{~m}$ man kommer till ett bra hem, så vill man ju stanna kvar där.«

\section{Familjetillhörighet till två familjer}

För de elva barnen i denna grupp (6 pojkar och 5 flickor) är både fosterföräldrarna och föräldrarna (vanligen mamman) personer, som de tycker mycket om. När barnen ska skriva en lista över viktiga personer, kommenterar de ofta varför de skriver fosterföräldrarna först och mamma (och eventuellt pappa) efter dem eller påpekar att »alla är lika viktiga egentligen «eller suddar och ändrar ordningen mellan fostermamma och mamma. Fosterföräldrarna kallas vid förnamn och jag hör bara en pojke ibland säga mamma och pappa till dem. Föräldrarna kallas alltid mamma och pappa.

Barnen i den här gruppen är Frida, Irene,
M alte, O Iga, Petra, Rasmus, Sven, Tobias, Ulla, Viktor, Å ke. O m vi jämför med tabell 1, finner vi att alla utom Frida och Irene (som tidigt placerades i släktinghem) kom till familjehemmet mellan fem och tio års ålder. Det innebär både att de bott tillsammans med och fått en bestående relation till sin mamma (utom möjligen Viktor). Det innebär också att de kan göra jämförelser med hur det var innan, hemma och/eller i annat fosterhem. När de talar om fosterhem och hem, ger de intryck av att göra medvetna val och ha tilltro till att de kan vara med och påverka (åtminstone föräldrar och fosterföräldrar, det är mer tveksamt med »socialen«). De har funderat över hur de ska kunna behålla två familjer, för de vill även fortsättningsvis ha till hörighet till båda. Jag väljer att ge varje barn ett eget utrymme:

Frida, som har bott hos sin mormor sen hon var liten, inser att det finns nackdelar med att bo hos mamma. sA ndra verkar tro att bara för att man bor hos sin mamma, så har man det jättebra, men där har dom fel. «Hon vill bo hos mormor men träffar mamma ofta, det är roligt att vara hos mamma också. Nu har hon stänkt på att åka till mamma ett par dar « Jo, visst vill mamma ha henne där, men hon har sagt att hon inte kan ta hand om henne, sfast hon vill « Sin pappa träffar hon ibland, men han bryr sig mer om sin flicka i ett senare förhållande, så det är inte alltid så roligt.

Irene, som bott hos sin moster sen hon var liten, har förut bott hos sin mamma över helgerna. Nu har hon också fătt kontakt med sin pappa, vilket lett till konflikt mellan mamma och moster och olika utredningar (vårdnadstvist och omprövning av LVU). Hon har bestämt att hon vill bo kvar i familjehemmet. En socialsekreterare har frågat många gånger, shon tror jag ändrar mig, men det gör jag inte, jag vill bo 
här « Nu fördelas helgerna mellan mamma, pappa och fosterföräldrarna. »Den tredje helgen skajag va hos mamma, det vill hon ju, men dom andra får jag bestämma själv, var jag ska va. I bland åker jag till pappa två hel ger och såär jag hemma (i fosterhemmet) en helg.«

$M$ alte bor hos sin mamma var tredje vecka, fredag till söndag. Det är roligt hos mamma, yiättekul där « Han tänker sig dock att bo länge i sitt familjehem, åtminstone tills han blir 18 år. ») ag tycker det är bra här « Men han vill vara hos mamma också och vjag får ju bo hos henne rätt länge, ibland har jag fått bo där två veckor « Jo, ibland har han tänkt på att flytta hem, men han vet att mamma inte orkar så mycket, hon är inte riktigt frisk. Nej, pappa vill han inte träffa, även om han gjort det någon enstaka gång, han tycker inte om honom.

Olga flyttade till sitt familjehem sör att mamma orkade inte med mig, och så tycker jag Signe och Sigge (fosterföräldrarna) är snälla, för den delen, i alla fall « Vartannat veckoslut, fredag till söndag, bor hon hemma hos mamma. Ibland tänker hon om framtiden: yag hoppas att jag får bo hos mamma. «Men det är bra i familjehemmet också och hon räknar självklart med att bo där, om inte mamma vill ha hem henne. Föräldrarna är skilda och pappa kommer bara på enstaka besök, al ltid tillsammans med farmor och farfar. Han har gjort något sganska äckligt « (sexuellt förgripit sig på henne), så honom vill hon inte gärna träffa.

Petra var förut varje helg hos mamma, men när mamma begärde at få hem henne blev det tvångsplacering. Innan det är klart i kammarrätten hur det blir, får mamma homma till henne istället. M amma är al koholist, smen jag tycker inte det är lönt att göra så himla stor sak av det, man bara gör det värre« Hon trivs bra hos sin fosterfamilj , som var stödfamilj innan, och det wvittar mig egentligen « vilketdera det blir, men hon har sagt till sin advoka: »...att jag vill bo hemma och att jag gärna bor här, men al Itså det ska vara under kanske varannan helg el ler så där. 0 m vi ska göra något särskilt på loven, kanske halva, om det är på sommarlovet eller så där, kan jag ju bo här varannan vecka kanske, och så på vanliga höstlov så där, kan jag bo halva lovet här och halva hos mamma och så där « Hon har ingen pappa, eftersom hon är adopterad av ensamstående mamma.

Rasmus har regelbundet besökt sin mamma, bott över hos henne både på behandlingshem och hemma. Näst efter fosterföräldrarna och deras barn är hon den viktigaste personen för honom. Han återkommer då och då till oro för at social sekretrare inte informerar i tid, som man kanske ska flytta, så man vet det några månader innan minst « På min fråga hur han helst skulle vilja ha det, vet han bestämt: 》yag skulle helst vilja bo här och vara helgbarn hos mamma... Jag har det så bra jag kan ha det (här).« För fosterföräldrarna är det OK, det har han försäkrat sig om, och jag förstår inte hans återkommande oro. Det visar sig att han inte är rädd för att vara tvungen att flytta hem till mamma, nej, han är rädd att socialen ska flytta honom till ett annat fosterhem, t.ex. inte tycker att fosterföräldrarna är bra, för att barnet inte sköter skolan ordentligt. Det är några år sen han träffade sin pappa, men ıdet är väl bra som det är, bara han inte dyker upp helt plötsligt «

Sven har bott på barnhem, i ett annat fosterhem och hemma hos mamma, innan han flyttade till mormor och morfar. yag trivs väldigt bra hos mormor och morfar. «D ärför bestämde han sig för att stanna kvar hos dem, när mamma slutat knarka och fătt hem lillebror från ett annat fosterhem. Vad säger mamma om det? 》y0, det får jag gärna, för jag åker ju och hälsar på henne. «Han bor hos mamma ungefär vartannat veckoslut och det är roligt att vara hemma hos henne också. Sin pappa talar han med ett par gånger om året. »łan är tönn, han är så dum. $\mathrm{H}$ an ljuger för mig i telefonen om min mormor och morfar och sånt.« 
Tobias hinner jag knappt informera om mitt forskningsprojekt, förrän han avbryter mig vid ordet sskillnad《 »a, at bo här är dubbelt så mycket skillnad, för att när vi bodde hemma var det bara bråk och sånt. «Han har en lång, smärtsam berättelse om föräldrarnas spritmissbruk och pappans misshandel av mamman och delvis också av barnen sför att vi stod på mammas sida« I fosterhemmet är det »roligt och skönt... dom är snälla och dom har bra regler « Han är fäst vid sin mamma också, som nu är på behandlingshem. »yag vill vara hos båda. D et är bra att vi åker till varandra och sånt, sen åker jag tillbaka till Tora (fostermamman) och så är vi här några veckor, sen åker vi till mamma, så vi turas om. «Han vet att han ska flytta hem till mamma så småningom, smen jag vill vara hos båda. Vi kanske kan göra så att jag bor hos mamma, så häl sar jag på hos Tora varenda helg eller så, varannan kanske« Han vill i varje fall inte flytta hem förrän han är säker på att mamma inte träffar pappa mer.

U lla har bott hos sin moster och hennes stora familj, sedan de hämtade henne från ett fosterhem, som de inte tyckte var bra. Själv trivdes hon bra, men både mamma och hon tyckte att fördelen med mosters familj var att de kunde träffas oftare. Hon har bott hos mamma på helgerna, men till sommaren ska hon flytta hem. Länsrätten gick med på att LVU upphörde. Själv var hon inte med i rätten, men hon hade talat med en advokđ, som framförde hennes åsikter. »D et var mitt tal och mammastal, som var så bra, så det var inget tvivel om att jag kunde flytta hem. «Hon kommer valltid « att träffa sin moster och hennesfamilj, det har hon ju »alltid « gjort innan, så »det blir kanske fyra gånger i månaden nu « Sin pappa tänker hon aldrig på, eftersom hon bara träffat honom när hon var ett år, ısen försvann han«

Viktor har bott i sitt familjehem ett drygt halvår. Innan dess bodde han »ett år och två månader «på barnhem. Innan dess bodde han sex år i annat fosterhem, men den tiden vill han inte tala om, har inga minnen med sig därifrån.
Det var på barnhemmet de hjälpte honom återfå kontakt med sin mamma och pappa. Det är uppenbart att han trivs bra i sitt nya fosterhem, är särskilt fäst vid sin fostermamma och det är här han vill bo. De uppmuntrar kontakten med pappan och det är meningen att han ska bo hos pappa varannan helg. Han är glad för sin pappa, som står bland de första på listan över viktiga personer, men det verkar inte riktigt som hans pappa motsvarar hans längtan, för som det var förra helgen »ligger han mest och sover « M amma kommer och hälsar på i fosterhemmet *anske varannan månad « sist sov hon över två nätter. $\mathrm{H}$ an träffar henne gärna shur många gånger som helst «

$\AA$ k ke är bror till Tobias och har likartade berättelser om missbruk och misshandel i hemmet. $\mathrm{H}$ an är mycket fäst vid fostermammans vuxna söner och fosterföräl drarna. »Nu är man fri och så kan man gå här ute i lugn och ro och sånt, utan att nån slåss. « När jag frågar något om shemma«undrar han om jag menar hos mamma på behandlingshemmet eller något av de 18 ställen de bott på. Jag ber honom då tänka på det hem som var bäst, men han säger: ‘’ är är bäst. «0 $m$ han fick bestämma, ıså tycker jag att mamma bodde nånstans och vi fick flytta hem, så hade vi åkt ut hit varannan helg och haft kontakt med Tora och Tore (fosterföräldrarna) och sånt. Så skulle jag vilja ha det « Vid en senare intervju är han mycket upprörd över att inte få stanna till sommaren, »det var ju avtalat《 M amma misstar sig, গ⿰ör hon tror att hon är tillräckligt stark, men hon är inte det « Han tänker i alla fall *omma och vara som kontaktbarn här... och så kommer jag att skriva brev och sånt «

Sammanfattningsvis är det ingen tvekan om att barnen är fästa vid fosterföräldrarna, tycker om dem, gärna stannar kvar hos dem och vill behålla kontakt med dem, om de flyttar hem. Det är heller ingen tvekan om at barnen också är fästa vid sin mamma och 
när det varit tal om att de skulle flytta hem, har det handlat om att flytta hem till mamma - barai två fall har det varit någon tanke på pappa. Barnen har resonerat med sig själva, hur de skulle kunna lösa frågan om att hålla kvar två familjer. Några har kommit fram till att det är bäst att bo kvar i familjehemmet och åka till mamma över helger. Andra har kommit fram till att, om de flyttar hem, så vill de vara i familjehemmet varannan helg eller hal va tiden. De vill ha båda och ser inget omöjligt i det, det är snarast den mest rimliga lösningen för dem.

\section{Diskussion}

Är det annorlunda att vara fosterbarn? Ur barnens perspektiv är det inte någon större skillnad mot hur »wanliga«barn har det (jfr Johannesen \& M almberg, 1993). Det kan på många sät vara bättre än att bo hemma, med de erfarenheter barnen har av att bo hemma. Hemma betyder då vanligen hemma hos mamma. Sin pappa har de inte lika nära förhåll ande till och en del känner honom inte alls. Även om barnen trivs brai sitt familjehem och vill bo kvar där, betyder det inte att de inte tycker om sin mamma. Hon kan vara en viktig person för dem, men det är inte samma sak som att vilja bo hos henne. $\mathrm{H}$ älften av barnen har sin tillhörighet i familjehemmet. Den andra hälften av barnen tillhör två familjer och det vill de fortsätta att göra, vare sig de bor kvar i familjehemmet el ler flyttar hem.

H ur ska man förstå barnens positiva uppfattning om sitt familjehem? Är det för att de anpassat sig väl i den situation, som de nödvändigtvis befinner sig i? Är det för att de är just 10-11 år och i en ålder då identitetspro- blematik ännu ligger (förhållandevis) latent? Är det för att de har föräldrar och fosterföräldrar, som klarat av att samarbeta eller att hålla barnen utanför samarbetsproblem (jfr Thoburn, 1994; Triseliotis et al, 1995; Wegler \& Warming, 1996). Är det för at deras fosterföräldrar är varma, engagerade personligheter (jfr Schaffer, 1995)? Är det för att barnen tror at jag förväntar mig en positiv bild av deras tillvaro, utan de problem som vanligen förknippas med separationer och fosterhemsplacering(ar)? $\mathrm{N}$ ej, de kan inte tro att det var, vad jag ville höra. Det tycks inte vara ovanligt att fosterbarn har en positiv uppfattning om sitt familjehem, om man ser på den begränsade forskning, som utgår från barns eget perspektiv (jfr Fletcher, 1993; Gardner, 1996).

Jag väljer att inte ifrågasätta barnens utsagor utan stannar vid att det är vad barnen säger, som är deras verklighet. Det är deras förståel se av sig själva, sitt liv och det sociala sammanhang, i vilket de ingår, som jag vill förmedla. Frågan är då i vad mån jag lyckats »ättvisande «förmedla något av det, som 22 barn sagt under cirka 66 timmars intervjutid. Jag har läst de utskrivna intervjuerna upprepade gånger och försökt att utifrån olika infallsvinklar finna mönster. Det jag förmedlar i artikeln, tror jag barnen känner igen sig i, om de läser vad jag skriver. Det kan tyckas märkligt at de fördelar sig så jämnt i två grupper med olika kännetecken, men jag finner inte att jag gjort »våld « på materialet. Det kan noteras att i Turid M idjos (1997) undersökning med 47 unga vuxna, 17-16 år, som växt upp i fosterhem, hade nästan hälften gjort fosterfamiljen till sin enda familj, sde entydigt fosterfamilieintegrerte«, medan nästan hälften inkluderade 
båda familjerna, »de tofamilieintegrerte« Bara några få av de f.d. fosterbarnen i hennes undersökning såg sin biologiska familj som sin enda familj.

Det barnen beskriver förtydligar en del av de erfarenheter, som jag sett tecken till i min tidigare forskning (Andersson 1984, 1988, 1990, 1995). Bibehållen föräldrakontakt är något annat än bibehållen fami ljetillhörighet. M an kan tycka om sina föräldrar, ha en rel ation till dem och ändå välja att inte bo tillsammans med dem. M an kan tillhöra två familjer och vilja ha båda ‘łör livet « Barnen är aktiva subjekt i de relationer, som utvecklas i förhållande till föräldrar och fosterföräldrar, och de tycks ha större tillit till att de olika föräldraparterna lyssnar på dem än att »socialen«gör det, vilket dock inte är ämne för den här artikeln.

Vad gäller barnens relationer till föräldrar och fosterföräldrar har jag här inte kunnat se tydliga skillnader mellan pojkar och flickor, vilket inte hindrar att det kan finnas skillnader ur andra aspekter än de, som granskatsi denna artikel.

Vanligen finner man att kontinuerlig kontakt mellan barn i fosterhem och deras föräldrar är väl görande för barnens självkänsla och identitet, hjälper dem att handskas med sina känslor, gör att de kan se sina föräldrar mer realistiskt och att de kan relatera bättre till sina fosterföräldrar. Det är emellertid inte givet att därav också följer oproblematiskt beteende och social anpassning, man kan inte dra några förhastade slutsatser om sådana samband (jfr C antos, Gries \& Slis, 1997; se även Vinnerljung, 1996 a). Jag vill påpeka att jag i denna artikel inte alls har gjort några kopplingar till barnens beteendeproblem, skolsvårigheter eller sociala anpassning - varken som den up pfattas av barnen eller deras fosterföräldrar. Jag låter barnens uppfattning om föräldrakontakt och familjetillhörighet ståför sig själv.

\section{Summary \\ Parental contact and family belonging from the perspective of foster children}

Children in Sweden are usually placed in foster homes because of social problems at home and the parents' (or the single mother's) neglect, for example due to drug addiction, mental illness or retardation. For a child under twelve the legal reason is the home environment and not the child's behaviour. Even if the intention of the law is reunion, children can stay in their foster homes for many years. What do children themselves say about foster care, about contact with their parents and about the relation to the birth family as well as to the foster family? These were some of the questions in the research project "Is there a difference in being a foster child?" and in this article foster children's perspectives on these questions are presented. Twenty-two children, all of them 10-11 years old and placed in foster homes by five child welfare offices (with nine children fall ling off), were interviewed three times with a few weeks in between. 0 nly one of them had parents living together, and for all the other children contact with the birth family actually was contact with the mother's and the father's 
family. It was shown that all children had contact with their mothers and half of them with their fathers too. The analysis of the children's answers showed that half of the children saw their foster family as their sole family and that half of the children felt that they belonged to the birth family (usually the mother's family) as well as to the foster family. For the first group contacts with the parents did not mean a feeling of belonging to the birth family. The second group saw no contrast in belonging to two families, and the children had ideas' to how to retain both, even if they were to return home. For foster children contact with or a good relation to the parents does not seem to be the same thing as wanting to move back home. The children's perspective is discussed.

\section{Referenser}

Ald gate, Jane (1990). Foster Children at School: Success or Failure? A doption \& Fostering, vol.14, no 4, 38-49.

Andenæs, A gnes (1991). Fra undersøkel seobjekt til medforsker? Livsformsintervju med 4-5-åringer. N ordisk Psykologi, 43 (4), 274-292.

Andersson, G unvor (1984). Små barn på barnhem. Lunds Universitet: Psykologiska Institutionen (akademisk avhandling).

A ndersson, G unvor (1988). En uppföljning av barn som skiltsfrån sina föräldrar. Lunds Universitet: M eddel anden från Socialhögskolan 1988:1.

Andersson, G unvor (1990). Barns förhåll ande till föräldrar och fosterföräldrar. N ordisk Psykologi , 42 (1), 59-74.

A ndersson, G unvor (1991). Socialt arbetemed små barn. Lund: Studentlitteratur.

Andersson, Gunvor (1995). Barn i samhällsvård. Lund: Studentlitteratur.

Andersson, G unvor (1998). Barnintervju som forskningsmetod. N ordisk Psykol ogi, 50 (1).

Andersson, G unvor, A ronsson, Karin, Hessle, Sven, Hollander, A nna \& Lundström, Tommy (1996). Barnet i den social a barnvården. Stockhol m: C entrum för utvärdering av socialt arbete/ Liber.

Barnombudsmannen (1994). H allå där! Rapport från ett uppdrag ur barnets perspektiv. Stockholm: Barnombud smannen.

Barth, Richard (1992). C hild welfare services in the United States and Sweden: different assumptions, laws and outcomes. Scandinavian Journal of Social Welfare, 1, 36-42.
Barth, Richard (1996). C hild welfare reform in the United States: changing populations, policies and principles. Scandinavian Journal of Social Welfare, 5, 159-164.

Bjerrum N ielsen, Harriet \& Rudberg, Monica (1991). Historien om flickor och pojkar. Könssocialisation i ett utvecklingspsykol ogiskt perspek tiv. Lund: Stu dentlitteratur.

Butler, lan \& Williamson, Howard (1994). C hildren Speak. C hildren, Trauma and Social Work. Essex: Longman.

Börjeson, Bengt (1976). I föräldrars ställe. Stockholm: Awe/G ebers.

Börjeson, Bengt \& Håkansson, Hans (1990). H otade, Försummade, Ö vergivna - är familjehemsplacering en mäjlighet för barn en? Stockholm: Rabén \& Sjögren.

C antos, A rthur L., G ries, Leonard T. \& Slis, Vikki (1997). Behavioral C orrelates of Parental Visiting During Family Foster $C$ are. C hild Welfare, vol. LXXVI, 2, 309-329.

Cederström, A nita (1990). Foster barnsan passning - en relationsproblematik. 0 m 25 barn i åldrarna 4-12 år som placeratsi fosterhem. En delstudiei Barn i kris-projektet. Stockholms universitet: Pedagogiska institutionen (akademisk avhandling).

C ederström, A nita \& H essle, M arie (1980). Barn i kris. Yt- och djupanpassning hos fosterbarn - en teoretisk förstudie. Stockhol ms social förvaltning, Barnbyn Skå, rapport nr 50.

Claussen, Clas . . (1992). Barnevernssvikt. Sosionomen, nr 16, 16-17. 
Egelund, Tine (1997). Beskyttel se af barndommen. Socialfor valtningers risikovurdering og indgreb. København: $\mathrm{H}$ ans Reitzels Forlag.

Eide, Brit (1989). »ntervju med barn»i LindhMunther, A ., red.,: Barninter vjun som forskningsmetod. Uppsal a Universitet: C entrum för barnkunskap, rapport om barn $\mathrm{nr} 1$.

Familjehemsvård i utveckling. En sammanställning av uppföljningar på länsnivå (1995). Stockholm: Socialstyrelsen.

Fanshel, David \& Shinn, E.B. (1978). C hildren in Foster Care. A Longitudinal Investigation. New York: C olumbia University Press.

Fletcher, Barbara (1993). N ot just a name. The views of young peopl ein foster and residential care. London: National C onsumer C ouncil.

G arbarino, James \& Stott, Frances M . (1992). W hat children can tell us. Eliciting, Interpreting, and Evaluating Critical Infor mation from C hildren. San Francisco: J ossey-Bass Publishers.

G ardner, H elen (1996). The C oncept of Family: Perceptions of $C$ hildren in Family Foster $C$ are. Child Welfare, vol.LXXV, 2, M arch-A pril, 161181.

Gilligan, Robbie (1997). Beyond permanence? A doption \& Fostering, vol. 21, nr 1, 12-20.

G oldsten, Joseph, Freud, A nna \& Sol nit, A lbert (1978). Barn ets rätt - eller rätten till barnet. Stockholm: Natur och Kultur.

Hagbard, Sigbritt \& Esping, Ulla (1991). M ed barns ögon. 0 m ett barnrel ater at förhållningssätt i familjehemsvården.Stockholm: A Ilmänna Barnhuset.

Halldén, Gunilla (1994). Familjen ur barns perspektiv. Socialveten skaplig tidskrift, nr 2-3, 103112.

Hessle, Sven (1988). Familjer i sönderfall. En rapport från samhäll svården. Stockhol m: Norstedts.

Hollander, Anna (1985). O mhänder tagandeav barn. Stockholm: A ktuell juridik förlag.

Holmes, Jeremy (1993). John Bowlby \& A ttachment Theory.London: Routledge.

Howe, David (1995). A ttachment Theor y for Social Work Practice. London: M acM illan.

James, A . \& Prout, A . (eds) (1990). C onstructing and Reconstructing $C$ hildhood: Contemporary
Issues in the Sociological Study of C hildhood. London: The Fal mer Press.

Johannesen, Jytte \& M almberg, M arie-Louise

(1993). Är det annorlunda att vara fosterbarn ett försök att se ur ett bar nperspektiv. Lunds Universitet: Social högskol an (opublicerad uppsats). Johnson, Penny Ruff, Yoken, C arol \& Voss, Ron

(1995). Family Foster C are Placement: The Child's Perspective. C hild Welfare, vol.LXX IV, 5, September-O ctober, 959-974.

Kjær J ensen, M ogens (1988). Interview med børn.

København: Social for skningsinstituttet, rapport 88:9.

Konventionen om barnets rättigheter (1990). Stockholm: Utrikesdepartementet, UD informerar 1990:6.

Lindén, G unilla (1982). Byta för äldrar - en bok om familjevårdens möjligheter och omöjligheter . Malmö: Liber.

Lindén, G unilla (1984). D en goda föräldern. 0 m samhällets roll vid omhändertagande av barn. N ordisk Psykol ogi, 36 (4), 211-227.

M cFadden, Emely J ean \& W hitel aw D owns, Susan (1995). Family C ontinuity: The New Paradigm in Permanence Planning. C ommunity A Iternatives. International J ournal of Family C are, vol.7, no $1,39-60$.

Midjo, Turid (1997). » ॠamiljerel asjoner og identitetsdannelsesi Backe-Hansen, E. \& Havik, T., red.,: B arnevern på barns premisser . O slo: Ad Notam Gyldendal.

Millham, Spencer, Bullock, Roger, H osie, Kenneth \& H aak, M (1986). Lost in care. The problem of maintaining links between children in careand their families. A ldershot: G ower. Dartington Social Research Unit.

Millham, Spencer, Bull ock, Roger, Hosie, Kenneth \& Little, M ichael (1989). Access di sputes in childcare. A ldershot: $\mathrm{G}$ ower. Dartington Research Unit.

O akley, Ann (1994). »W omen and C hildren First and Last: Parallells and Differences between Children's and Womens's Studies«i M ayall, B.,ed.,: C hildren 's $C$ hildhoods: 0 bserved and Experienced. London: The Falmer Press.

Patterns \& $O$ utcomes in C hild Placement. M essages from current research and their implications 
(1991). London: HM SO

Prop. 1996/97:124. Regeringens proposition. Ändring i socialţänstlagen. Stockholm: Riksdagens tryckeriexpedition.

Q vortrup, Jens, Bardy, M arjatta, Sgritta, G iovanni \& Wintersberger, Helmut (eds) (1994). C hildhood $M$ atters. Social Theor y, Practice and Politics. A ldershot: A vebury, European C entre Vienna.

Rasmusson, Bodil (1994). Barnperspektiv. Reflektioner kring ett mångtydigt och förän derligt begrepp. Lund: Barnombudsmannen.

Riksdagens Revisorer (1991/92:4). Familjehemsvård för barn och ungdom. Stockholm: Riksdagens revisorer Dnr 1990:83.

Rskr Riksdagsskrivel se 1992/93:16. U ppdrag om familjehemsvården. Stockholm: Socialdepartementet.

Rutter, M ichael (1990). ‘’sychosocial resilience and protective mechani sms«i Rolf, J., M asten, A.S., Ciccetti, D ., Neuchterlein, K.H. \& Weintraub, S., eds.,: Risk and protectivefactors in the devel opment of psychopathol ogy. C ambridge: $C$ ambridge University Press.

Schaffer, Rudolph H. (1995). Beslut om barn. Psykologisk a frågor och svar . Lund: Studentlitteratur.

Social tjänst 1997:11. Insatser för barn och unga 1996. Stockholm: Socialstyrel sen.

SoS-rapport 1990:4. Vård utom hemmet. Stockholm: Socialstyrelsen.

SoS-rapport 1996:19. Barn i fokus-projektet. Slutrapport. Stockholm: Social styrel sen.

SOU Statens O ffentliga Utredningar (1986:20). Barns behov och föräldrars rätt. Socialtjänstens ar betemed utsatta familjer. Betänkande av socialberedningen. Stockholm: Socialdepartementet.

SOU Statens O ffentliga Utredningar (1994:139). N y socialtiänstlag. Hu vudbetänkande av Socialtjänstkommittén. Stockhol m: Socialdeparetmentet.

SOU Statens O ffentliga Utredningar (1997:116). Barnets bästa i främsta rummet. Barnkommitténs huvudbetänkande. Stockholm: Socialdepartementet.«

Stone, Wendy L. \& Lemanek, Kathleen L. (1990). ¿D evel opmental Issues in C hildren's
Self-Reports«i La G reca, A.M.,ed.,; T hrough the eyes of the child. $O$ btaining Self-Repor ts from Children and Adolescents. Boston: A llyn and Bacon.

Thoburn, June (1990). Success and Failurein Permanent Family Placement. A ldershot: $G$ ower.

Thoburn, June (1994). C hild Placement: Principles and practice. Alder shot: A rena.

Tiller, Per O lav (1988). »Barn som sakkyndige informanter « Kjær J ensen, M ., red.,; Interview med børn. København: Social forskningsinstituttet, rapport 88:9.

Tiller, Per O lav (1991). »Barnper spektivet « 0 må se og bli sett. Vårt perspektiv på barn - eller omvendt? Barn. N ytt fra Forskning om Barn, nr 1,72-77.

Triseliotis, John, Sellick, Clive \& Short, Robin (1995). Foster Care. Theory and Practice. London: Batsford.

Wegler, Bibi \& Warming, Hanne (1996). Barnet mellem to familier - en under søgel seaf samarbejdet mellem forældreog plejefor ældre. Fredrikshavn: $\mathrm{D}$ afolo Forlag.

Wells Kathleen \& Tracy Elisabeth (1996). Reorienting Intensive Family Preservation Services in Rel ation to Public C hild Welfare Practice. Child Welfare, vol LXXV, 6, 668-692.

Werner, Emmy E. \& Smith, Rut S. (1982). Vulnerablebut Invincible: A Longitudinal Study of Resilient Children and Youth. New York: M CG rawHill.

Werner, Emmy E. \& Smith, Rut S. (1992). 0 vercoming the $\mathrm{O} d d s$. $\mathrm{H}$ igh Risk $\mathrm{C}$ hildren from Birth to Adulthood. N ew York: C ornell University Press.

Vestby, Guri (1991). Det er detajene som teller. Barn. N ytt fra forskning om barn i N orge, $n r 4$, 37- 44.

V innerljung, Bo (1996 a). Fosterbarn som vuxna. Lund: A rkiv (akademisk avhandling).

Vinnerljung, Bo (1996 b). Svensk for skning om fosterbarn. En över sikt. Stockholm: C entrum för utvärdering av socialt arbete/Liber.

Vinterhed, Kerstin, Börjeson, Bengt, C ederström, Anita, Fredin, Erik, Hessle, M arie \& Hessle, Sven (1981). Barn i kris. En bok om barn och separation. Stockholm: A lmqvist \& Wiksell. 